\title{
In vitro digestibility and fermentation ruminant of buffalo ration based on Neptunia plena L. Benth and Leersia hexandra Swartz as local resources
}

\author{
Hamdi Mayulu $^{1) *}$, Suyadi $^{2)}$, M. Christiyanto ${ }^{3)}$, Sunarso $^{3)}$, T. P. Daru ${ }^{1)}$ and Muh. I. Haris ${ }^{1)}$ \\ 1) Animal Sciences Departement of Agricultural Faculty, Mulawarman University, Kampus \\ Gunung Kelua Jalan Pasir Belengkong Samarinda, Kalimantan Timur, 75123, Indonesia \\ 2) Faculty of Animal Husbandry, Brawidjaya University, Jl. Veteran Malang, Jawa Timur, \\ 65145, Indonesia \\ ${ }^{3)}$ Diponegoro University, Kampus drh. Soejono Koesoemowardoyo, Jl. Prof. Sudarto No.13, \\ Tembalang, Kec. Tembalang, Kota Semarang, Jawa Tengah, 50275, Indonesia
}

Submitted: 16 October 2019, Accepted: 01 June 2020

\begin{abstract}
Utilization of local resource (Neptunia plena L. Benth and Leersia hexandra Swartz) as feed ration for buffalo fattening could make cost efficiency, fulfil primary life needs and production. The objectives of study is to determine the Dry Matter Digestibility (DMD), Organic Matter Digestibility (OMD), $\mathrm{NH}_{3}$ ruminant fermentation and Volatile Fatty Acid (VFA). The conduct of the study was in Laboratory of Animal Husbandry Nutrient Science, Faculty of Animal Science and Agriculture, Diponegoro University, Semarang by using in vitro method with a Complete Randomized Design (CDR) of five treatments and five replicates: (1) $\mathrm{T}_{1}=100 \%$ Leersia hexandra Swartz; (2) $\mathrm{T}_{2}=100 \%$ Neptunia plena L.Benth; (3) $\mathrm{T}_{3}=$ Ration (15\% Neptunia plena L.Benth $+15 \%$ Leersia hexandra Swartz $+70 \%$ other feedstuffs); (4) $\mathrm{T}_{4}$ $=$ Ration $(20 \%$ Neptunia plena L.Benth $+20 \%$ Leersia hexandra Swartz $+60 \%$ other feedstuffs); and (5) $\mathrm{T}_{5}=$ Ration $(25 \%$ Neptunia plena L.Benth $+25 \%$ Leersia hexandra Swartz $+50 \%$ other feedstuffs). Data analysis used analysis of variance with a significance level of 95\% and then followed by Duncan Multiple Range Test (DMRT). The results showed that $\mathrm{T}_{3}$ and $\mathrm{T}_{4}$ treatments produced the highest $\mathrm{DMD}$ at $(\mathrm{P}<0.05)$, i.e. $43.65 \%$ and $43.26 \%$, respectively. $\mathrm{T}_{2}$ treatment $(47.66 \%)$ significantly produced the highest OMD $(\mathrm{P}<0.05)$ compared to $\mathrm{T}_{4}(46.81 \%)$ and $\mathrm{T}_{1}(45.36 \%)$. $\mathrm{T}_{5}$ treatment $(5.28 \mathrm{mM})$ significantly produced in the highest $\mathrm{NH}_{3}(\mathrm{P}<0.05)$ compared to $\mathrm{T}_{2}(4.88 \mathrm{mM}) ; \mathrm{T}_{3}(4.73 \mathrm{mM})$; and $\mathrm{T}_{1}(4.43 \mathrm{mM})$. $\mathrm{T}_{5}$ treatment $(145.4 \mathrm{mM})$ significantly produced the highest VFA $(\mathrm{P}<0.05)$ compared to $\mathrm{T}_{4}(140.0$ $\mathrm{mM}) ; \mathrm{T}_{3}(135.4 \mathrm{mM}) ; \mathrm{T}_{2}(134.8 \mathrm{mM}) ;$ and $\mathrm{T}_{1}(123.6 \mathrm{mM})$. In vitro digestibility and fermentation ruminant of buffalo ration based on Neptunia plena, L. Benth, and Leersia hexandra Swartz as local resources can buffalo improved ruminant fermentation so that it is capable of increasing the buffalo productivity.
\end{abstract}

Keywords: Fermentation; Ruminant; Digestibility; Ration; Buffalo

*Corresponding Author: mayoeloehsptno@yahoo.com 


\section{INTRODUCTION}

Food production system consists of several components, including livestock which importantly contributes to quality and variety of meat supply (Wanapat et al., 2013). Ruminant production is more competitive and oriented towards sustainability, a decent and economical production system (Goes et al., 2019). Buffalo (Bubalus bubalis) also has the potential to produce meat in addition to other livestock such as cattle, goats and sheep (Nanda and Nakao, 2003). The population of buffalo in Indonesian in 2018 was 1.356 .390 heads, with meat production reaching to 31.30 thousand tons. East Kalimantan Province with geographic potential (climate and land), as well as the carrying capacity of its feed, has the potential to become a buffalo development area. The population of buffalo in East Kalimantan Province in 2018 was 7.124 heads with a level of meat production reaching to 59 tons (Ministry of Agriculture, 2018).

The interaction between genetic, feed and fattening management determines livestock productivity, including reproductive productivity. A feed is the largest component in production cost. The high cost of feed ingredients causes an increase in production cost, so it is necessary to do efficiency (Goes et al., 2019). Utilizing local feed resources can help to reach the efficiency of feed cost that are available continuously throughout the year, not competing with humans, the quality and quantity can meet the needs of livestock production and reproduction (Wanapat and Rowlinson, 2007). Buffalo, with their existing digestive system, can adapt well to the extreme environment and feed quality with high crude fibre content (Wanapat et al., 2013). Supan-supan legumes (Neptunia plena L. Benth) and Kolomento grass (Leersia hexandra Swartz) are local feed resources which capable for the feed ingredient for buffalo ration. Evaluation of feed ingredient aims to determine the best type of feed, optimize the provision of ration, and find out the potential feed digested by livestock.

Digestion is an early indication of the availability of various nutrients contained in the feed. Digestibility and fermentation rate test can be carried out by in vitro method (Khanum et al., 2007). The in vitro method is an alternative method to estimate feed degradation in livestock's digestive apparatus, especially ruminants without involving the animal (Mohamed and Chaudhry, 2008).

Addition of Neptunia plena L. Benth and Leersia hexandra Swartz aimed at providing cheap feedstuff because of abundant availability and has a nutrient composition which capable of fulfilling needs of buffalo. Utilization of local feed resources composed in the form of the ration with a combination of other feed ingredients becomes an alternative way in providing buffalo ration, so it needs further study at the testing stage on livestock on an experimental scale.

\section{MATERIALS AND METHODS}

The study was in at the Laboratory of Animal Husbandry Nutrition Science, Faculty of Animal Husbandry and Agriculture, Diponegoro University, Semarang (December 2018). The research used several stages as a series of activities.

\section{Preparation of sample and rumen inoculum}

Preparation of feed material sample used physical treatment, namely: cutting, drying, and grinding, so that the sample was mash-shaped. Samples test is using proximate analysis (Table 1) to determine their nutrient content. Local feed resources (Neptunia plena L. Benth and Leersia hexandra Swartz), and other feed ingredients composing ration (rice bran, maize, palm oil cake, and calliandra) came from wild grasslands, agricultural byproducts, and plantations in Samarinda City, East Kalimantan Province. Buffalo rumen liquid was originally from Slaughterhouse 
Boestaman Semarang collected at dawn, then filtered and put into a thermos that had been filled with warm water beforehand to a temperature of $39^{\circ} \mathrm{C}$, then closed the lid to maintain an anaerobic atmosphere, then taken to the laboratory for analysis. The nutrition content of feedstuff ration was analyzed used proximate analysis (AOAC,1990) which includes moisture content (MC), ash, crude protein (CP), ether extract (EE), crude fibre (CF), and material extract without nitrogen (NFE). The result of the proximate analysis of feedstuff showed in Table 1.

Tabel 1. Nutrient content of feedstuff

\begin{tabular}{lcccccc}
\hline \multirow{2}{*}{\multicolumn{1}{c}{ Feedstuff }} & \multicolumn{7}{c}{ Nutrient Content (\%) } \\
\cline { 2 - 7 } & DM & Ash & OM & CF & CP & NFE \\
\hline Leersia hexandra Swartz & 85.09 & 9.57 & 90.43 & 49.23 & 11.28 & 27.93 \\
Neptunia plena L. Benth & 86.89 & 4.82 & 95.18 & 54.76 & 15.49 & 21.73 \\
Maize & 89.97 & 0.77 & 99.23 & 0.38 & 8.14 & 89.13 \\
Rice Bran & 88.91 & 5.49 & 94.51 & 24.75 & 9.97 & 53.82 \\
Palm oil cake & 92.27 & 1.37 & 98.63 & 48.78 & 14.03 & 15.17 \\
Calliandra & 93.54 & 11.35 & 88.65 & 55.84 & 23.86 & 6.72 \\
\hline
\end{tabular}

Source: Proximate analysis result from Laboratory of Animal Nutrition Science, Faculty of Animal Husbandry and Agriculture, Diponegoro University, Semarang (2017).

\section{Research materials}

Buffalo ration ingredients were Neptunia plena L. Benth, Leersia hexandra Swartz, rice bran, maize, palm oil cake and calliandra. The ration was made based on DM and already met the lower and upper limit of CP needs for livestock, ranging from $10-14 \%$ with TDN 60\% (Sunarso, 2003). Protein and energy balance is significantly needed by rumen during fermentation (Rodriguez et al., 2015). Materials used for in vitro analysis were Mc Dougall's solution (artificial saliva), pepsin-HCL solution, ice water, distilled water, $\mathrm{CO}_{2}$, methyl red and bromocresol green indicator, saturated sodium carbonate $\left(\mathrm{Na}_{2} \mathrm{CO}_{3}\right)$, sulfuric acid $\left(\mathrm{H}_{2} \mathrm{SO}_{4}\right) 15 \%$, boric acid solution, $\mathrm{HCl}$ $0,5 \%$, sulfuric acid $0,0055 \mathrm{~N}$, phenolphthalein indicator $1 \%$, vaseline, $\mathrm{NaOH} 0,5 \mathrm{~N}$, and Whatman filter paper 41 .

\section{Experimental design}

The experimental design uses a Complete Randomized Design (CRD) with five treatments and five replicates. The main consideration in ration projection followed the balance of CP content of $11 \%-12 \%$, with the ration energy content calculated based on Total Digestible Nutrient (TDN) $\pm 60 \%$. The balance limit of ration was in the range between the lowest limit of $\mathrm{CP}$ for ruminant, i.e. $10 \%$ and the highest limit of $\mathrm{CP}$ for ruminant, i.e. $14 \%$ and the energy requirement (TDN) was $\pm 60 \%$. Addition of leguminous calliandra to ration aimed to achieve the balance of $\mathrm{CP}$ and utilize sufficiently feedstuff in East Kalimantan, particularly in Samarinda.

The treatments consisted of $\mathrm{T}_{1}=100 \%$ Leersia hexandra Swartz; $\mathrm{T}_{2}=100 \%$ Neptunia plena $\mathrm{L}$. Benth; $\mathrm{T}_{3}, \mathrm{~T}_{4}$, and $\mathrm{T}_{5}$ ration which formulated from Leersia hexandra Swartz, Neptunia plena L. Benth, maize, rice barn and palm oil cake with a composition of $\mathrm{T}_{3}=12 \% \mathrm{CP}$ and TDN $60 \%$; $\mathrm{T}_{4}=11.92 \%$ CP and TDN 59.80\%; $\mathrm{T}_{5}=$ $11.68 \% \mathrm{CP}$ and TDN $59.39 \%$ (Table 2).

\section{In vitro method}

In vitro method of Tilley and Terry is a well-known method to evaluate the utilization amount of ruminant feed nutrients. This method had two stages, namely fermentative digestion using rumen fluid buffer for 48 hours and enzymatic digestion with a pepsin-HCL solution for 48 hours (Tilley and Terry, 1963; Mabjeeshh et al., 2000; Makkar, 2004). In vitro analysis was started with the preparation of sample and research materials, then poured $10 \mathrm{ml}$ of buffalo rumen liquid and added with $40 \mathrm{ml}$ of Mc Dougall solution into a $50 \mathrm{ml}$ 
measuring cup until obtaining a homogeneous mixture. Then, the mixture put into a fermenter tube that had been filled with treatment samples as much as 0.55$0.56 \mathrm{~g}$. The fermentor cylinder was then closed. The little amount of $\mathrm{CO}_{2}$ gas added into the fermentor in order to get anaerobic condition inside the fermentor tube.
Fermenter tubes incubated the containing treatment sample with the help of a water bath (temperature $39^{\circ} \mathrm{C}$ ). Microbial fermentation happened for 48 hours, wellshaken for every six hours. The microbial fermentation process stopped after 48 hours by moving the fermenter tube from the water bath into a container filled with ice

Table 2. Chemical composition of each ration (\% dry matter)

\begin{tabular}{|c|c|c|c|c|c|}
\hline \multirow{2}{*}{ Composition } & \multicolumn{5}{|c|}{ Treatment } \\
\hline & $\mathrm{T}_{1}$ & $T_{2}$ & $\mathrm{~T}_{3}$ & $\mathrm{~T}_{4}$ & $\mathrm{~T}_{5}$ \\
\hline \multicolumn{6}{|c|}{ 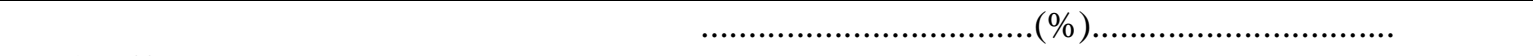 } \\
\hline Feedstuff: & & & & & \\
\hline Leersia hexandra Swartz & 100.00 & - & 15.00 & 20.00 & 25.00 \\
\hline Neptunia plena L.Benth & - & 100.00 & 15.00 & 20.00 & 25.00 \\
\hline Maize & - & - & 34.00 & 39.00 & 42.00 \\
\hline Rice barn & - & - & 14.00 & 9.50 & 1.00 \\
\hline Palm oil cake & - & - & 14.50 & 3.00 & 2.00 \\
\hline Calliandra & - & - & 7.50 & 8.50 & 5.00 \\
\hline Total & 100.00 & 100.00 & 100.00 & 100.00 & 100.00 \\
\hline \multicolumn{6}{|l|}{ Feed nutrient: } \\
\hline $\mathrm{DM}$ & 85.09 & 86.89 & 89.92 & 89.65 & 88.69 \\
\hline $\mathrm{OM}$ & 90.43 & 95.18 & 94.30 & 94.27 & 94.42 \\
\hline $\mathrm{CP}$ & 11.28 & 15.49 & 12.00 & 11.92 & 11.68 \\
\hline $\mathrm{TDN}^{*}$ & 40.88 & 38.38 & 60.00 & 59.80 & 59.39 \\
\hline
\end{tabular}

Source: Proximate analysis result from Laboratory of Animal Nutrition Science, Faculty of Animal Husbandry and Agriculture, Diponegoro University, Semarang (2017).

*Calculation result, according to Sutardi (2001)

water, then centrifuged at a speed of $3000 \mathrm{rpm}$ for 15 minutes. The clear liquid (supernatant) had separated from the residue before carried out an enzymatic digestive process on the sediment. Enzymatic digestion happens by adding $50 \mathrm{ml}$ pepsinHCL solution into the fermenter tube containing centrifuge precipitate. The fermentor tube was then incubated into the water bath at a temperature of $39^{\circ} \mathrm{C}$ for 48 hours and shake every six hours. The next process was taking residue and filtering it using Whatman 41 filter paper assisted with a vacuum pump. The produced residue was put into crucible porcelain and put into an oven at $105^{\circ} \mathrm{C}$ for 12 hours. The sample heated inside the oven was cooled using a desiccator for 15 minutes and weighed it using analytical scales.

\section{Statistic calculation and analysis}

Parameters of Dry Matter Digestibility (DMD), Organic Matter Digestibility (OMD), $\mathrm{NH}_{3}$ fermentation level and Volatile Fatty Acid fermentation (VFA) level uses these following equations (Mayulu et al., 2018):

1. DMD equation:

DM Digestibility $=\frac{\text { DM weight of the sample }-(\text { DM contained in residue }- \text { blanco })}{\text { DM weight of the sample }} \times 100 \%$.

2. OMD equation:

$\mathrm{OM}$ digestibility $=\frac{\mathrm{OM} \text { weight of sample }-(\mathrm{OM} \text { contained in residue }- \text { blanco })}{\text { OM weight of the sample }} \times 100 \%$ 
Remarks:

DM sample = sample weight $\mathrm{x} \% \mathrm{DM}$

$\mathrm{DM}$ residue = weight after oven-CP-filter paper

Blanco = weight after oven-CP- filter paper

OM sample = weight of DM sample $\mathrm{x} \% \mathrm{OM}$

$\% \mathrm{OM}=100 \% \mathrm{DM}-(\%$ ash inside $\mathrm{DM})$

$\mathrm{OM}$ residue = weight after oven - weight after tenure - filter paper

3. Ammonia $\left(\mathrm{NH}_{3}\right)$ production equation:

$\mathrm{NH}_{3}$ production $(\mathrm{mM})=\left(\mathrm{ml}\right.$ titrant $\left.\times \mathrm{N} \mathrm{H}_{2} \mathrm{SO}_{4} \times 1000\right)$

Remarks: $\mathrm{N}=\mathrm{H}_{2} \mathrm{SO}_{4}$ solution normality

4. VFA production equation:

VFA Production $(\mathrm{mM})=(\mathrm{a}-\mathrm{b}) \times \mathrm{N} \mathrm{HCl} \times 1000 / 5$

Remarks:

$$
\mathrm{a}=\text { Titran volume of the blanco }(\mathrm{ml})
$$

\section{Statistical analysis}

The result obtained from in vitro was then analyzed by using analysis of variance (ANOVA) at significance level $95 \%$ and then followed by Duncan Multiple Range Test (DMRT) by using CoStat program approach.

\section{RESULTS AND DISCUSSION}

Buffalo is a ruminant that capable of changing low-quality feedstuff (high fibre) to becomes quality of food products (meat) which has rich in nutrition. Buffalo is more efficient in digesting crude fibre, ruminant nitrogen ammonia $\left(\mathrm{NH}_{3}-\mathrm{N}\right)$, recycling nitrogen $(\mathrm{N})$, degrading dry matter and crude protein compared to cattle (Sarwar et al., 2009; Wanapat et al., 2013). The efficient digestion in buffalo happens due to the diversity of rumen microorganisms including cellulolytic bacteria (Fibrobacter succinogenes, Ruminococcus albus and Ruminococcus flavefaciens species) which are dominant and contribute in fibre degradation and are supported by the presence of protozoa (Holotrichs, Entodiniomorphs) which role in digesting fermentable carbohydrate, and capable of fermenting sugar (sugar, starch) (Wanapat $e t$ al., 2013). Ruminants are very dependent on forage as the main source of feed, but their

$$
\mathrm{b}=\text { Titran volume of the sample }(\mathrm{ml})
$$

availability fluctuates and depends on the season, so the quality and quantity are uncertain (Makkar, 2004; Wanapat and Rowlinson, 2007). Biological evaluation of feed on a laboratory scale through a quantitative approach (in vitro method) is to predict feed quality. Digestion is a parameter in determining the number of feed nutrients that can be utilized in the body of livestock and absorbed by the digestive tract (gastrointestinal tract) in supporting maintenance, production, and reproduction (Makkar, 2004; Dijkstra et al.,2005; Mould et al., 2005; Mayulu et al., 2018).

\section{Dry matter and organic matter digestibility}

A good quality ration depends on the nutrient content and the level of nutrient utilization in the animal's body. Dry matter digestibility (DMD) is the ability of animals to digest and utilize dry matter contained in the ration given. As seen in Table 3, means of in vitro DMD of buffalo ration based on local feedstuff, based on ANOVA, showed the highest $\mathrm{DMD}$ average value, i.e. $\mathrm{T}_{3}=43.65 \% ; \mathrm{T}_{4}=43.26 \% ; \mathrm{T}_{5}=39.87 \%$; $\mathrm{T}_{1}=37.81 \%$; and $\mathrm{T}_{2}=36.96 \%$. DMRT results showed that $\mathrm{T} 3$ produced the highest DMD, but it was not significantly different from $\mathrm{T}_{4}$. Treatment $\mathrm{T}_{3}$ was significantly higher $(\mathrm{P}<0.05)$ compared to $\mathrm{T}_{5}, \mathrm{~T}_{1}$, and $\mathrm{T}_{2}$. 
Table 3. Means of in vitro dry matter and organic matter digestibility of buffalo treatment ration

\begin{tabular}{|c|c|c|c|c|c|}
\hline \multirow[b]{2}{*}{ Parameter } & \multicolumn{5}{|c|}{ Treatment } \\
\hline & $\mathrm{T}_{1}$ & $\mathrm{~T}_{2}$ & $\mathrm{~T}_{3}$ & $\mathrm{~T}_{4}$ & $\mathrm{~T}_{5}$ \\
\hline DMD & $37.81^{b c} \pm 3.4$ & $36.96^{\mathrm{c}} \pm 0.8$ & $43.65^{\mathrm{a}} \pm 0.4$ & $43.26^{\mathrm{a}} \pm 0.8$ & $39.87^{b} \pm 1.7$ \\
\hline OMD & $45.36^{\mathrm{c}} \pm 0.02$ & $47.66^{\mathrm{a}} \pm 0.22$ & $47.12^{\mathrm{ab}} \pm 0.13$ & $46.81^{b} \pm 0.08$ & $47.36^{\mathrm{ab}} \pm 0.01$ \\
\hline
\end{tabular}

Remark: Different superscript shows significant difference in the same line $(\mathrm{P}<0.05), \mathrm{T}_{1}=100 \%$ Leersia hexandra Swartz; $\mathrm{T}_{2}=100 \%$ Neptunia plena $\mathrm{L}$.Benth; $\mathrm{T}_{3}=$ Ration $(15 \%$ Neptunia plena $\mathrm{L}$. Benth $+15 \%$ Leersia Swartz hexandra $+70 \%$ other feedstuffs); $\mathrm{T}_{4}=$ Ration $(20 \%$ Neptunia plena L.Benth $+20 \%$ Leersia hexandra Swartz $+60 \%$ other feedstuffs); $\mathrm{T}_{5}=$ Ration $(25 \%$ Neptunia plena $\mathrm{L}$. Benth $+25 \%$ Leersia hexandra Swartz $+50 \%$ other feedstuffs).

The result recommends the utilization of local feed e of 15 and 20 in the ration, based on the results of the study showed that DMD of $\mathrm{T}_{3}$ and $\mathrm{T}_{4}$ was $43.65 \%$ and $43.26 \%$, respectively. Those values were better when compared to the utilization of single feed $\mathrm{T}_{1}$ (100\% Leersia hexandra Swartz) and $\mathrm{T}_{2}$ (100\% Neptunia plena L. Benth) with the value of $37.81 \%$ and $36.96 \%$, respectively (Table 3). However, the results of DMD were lower when compared to studies conducted by Sugoroet al. (2015) who found that in vitro buffalo ration composed of local feed (50\% sorghum straw silage) and 50\% concentrate where the highest DMD was $62.93 \%$. This low digestibility value happens due to crude fibre contained in the feedstuffs, according to the opinion of Mayulu (2014) which stated that low digestibility because of alkaloid and crude fibre content. The difference in digestibility values depends on several factors including the physical form of feedstuff, nutrient content, feedstuff, composition comparison among the feedstuffs, treatment of the feed and the period of stay inside the rumen (Mabjeesh et al., 2000; Sugoro et al., 2015; Mayulu et al., 2018).

The activity of rumen microorganism can determine the level of feed digestibility because rumen microbial activity depends on nutrient contained in feedstuffs (Mayulu et al., 2018). The feedstuffs that have high crude fibre content can cause low digestibility, while feedstuffs with low crude fibre generally have higher digestibility, this is because the cell walls of the feedstuff are thin so that they can be penetrated by digestive sap (Mayulu et al., 2018).

Organic Matter Digestibility (OMD) is a percentage of the amount of organic matter in a feed or ration that can be digested by the digestive tract and subsequently will be utilized by the livestock body and rumen microorganisms to produce energy or Volatile Fatty Acid (VFA) (Mayulu, 2015). The organic matter digestibility is closely related to DMD because some DM is OM which consists of crude protein, crude fat, crude fibre and Nitrogen Free-Extract (NFE). Organic matter acts as a source of energy in supporting metabolic processes in the body (Mayulu, 2015).

As seen in Table 3, means of in vitro OMD of buffalo ration based on local feedstuff, based on ANOVA, showed the highest $\mathrm{OMD}$ average value of $\mathrm{T}_{2}=47.66 \%$; $\mathrm{T}_{5}=47.36 \% ; \mathrm{T}_{3}=47.12 \% ; \mathrm{T}_{4}=46.81 \%$ and $\mathrm{T}_{1}=45.36 \%$. Duncan, multiple range test results, showed that $T_{2}$ produced the highest DMD, but it was not significantly different from $T_{3}$ and $T_{5}$. Treatment $T_{2}$ was significantly higher $(\mathrm{P}<0.05)$ compared to $\mathrm{T}_{4}$ and $\mathrm{T}_{1}$. The result showed that the utilization of single feed $\mathrm{T}_{2}(100 \%$ Leersia hexandra Swartz) produced the highest OMD of $47.66 \%$. However, this result was lower when compared to studies conducted by Sugoro et al. (2015) who found that the highest DMD to in vitro buffalo ration composed of local feed (50\% sorghum straw 
silage) and $50 \%$ concentrate was $59.97 \%$. This low OMD value happens due to the activity of rumen microorganisms, nutrient content of feed ingredients (high crude fibre content) and too small of feed particle size which causes decreasing of feed flow rate leaving the rumen and having an impact on reducing the chance of rumen microbes to degrade feed particles. Mayulu (2015) stated that the low OMD value could cause by the high content of neutral detergent fibre (NDF) cell walls in the ration.

\section{Parameter of $\mathrm{NH}_{3}$ ruminant fermentation and VFA}

Pure protein and non-protein nitrogen (NPN) are feed protein that enters the rumen and degraded into peptide and amino acid. The degradation results will produce the final product in the form of ammonia $\left(\mathrm{NH}_{3}\right)$ and other products such as VFA and carbon dioxide $\left(\mathrm{CO}_{2}\right)$ (Christiyanto et al., 2005). Ammonia is the main nitrogen source for protein synthesis of rumen microorganism, $\mathrm{NH}_{3}$ formation in the rumen is highly dependent on the chemical structure of the protein contained in the ration material (Christiyanto et al., 2005; Mayulu, 2015; Aderinboye et al.,2016; Phesatcha dan Wanapat, 2016). $\mathrm{NH}_{3}$ level needed to support the maximum rumen microbial biosynthesis is 3.57-7.14 mM (Sunarso, 2003; Mayulu, 2015). Buffalo rumen microbes have high efficiency in utilizing NPN for microbial protein synthesis. The means of $\mathrm{NH}_{3}$ production of buffalo ration based on local feed in-vitro (Table 4), based on ANOVA shows the average value of the highest $\mathrm{NH}_{3}$ production wasT $=5.28 \mathrm{mM}$; $\mathrm{T}_{4}=5.20 \mathrm{mM} ; \mathrm{T}_{2}=4.88 \mathrm{mM} ; \mathrm{T}_{3}=4.73 \mathrm{mM}$ and $\mathrm{T}_{1}=4.43 \mathrm{mM}$. Duncan's multiple range test results showed that $\mathrm{T}_{5}$ produced the highest NH3 production, but it was not significantly different from $\mathrm{T}_{4}$. $\mathrm{T}_{5}$ treatment showed significantly higher results ( $\mathrm{P}$ $<0.05$ ) compared to $T_{2}, T_{3}$, and $T_{1}$.

The highest $\mathrm{NH}_{3}$ production was produced by $\mathrm{T}_{5}(5.28 \mathrm{mM})$ treatment, which contained crude protein $11.68 \%$ and TDN $59.39 \%$. These results indicate that $\mathrm{T}_{5}$ treatment ration is in the range of optimum $\mathrm{NH}_{3}$ concentration (3.57-7.14 mM) so that it can support the biosynthesis of rumen microbes. The difference in $\mathrm{NH}_{3}$ production in this study probably happens because of the amount of protein in the ration, protein solubility, and the degradation rate of feed protein. Low $\mathrm{NH}_{3}$ production can cause rumen microbial growth to be slow, resulting in inhibited carbohydrate degradation.

Table 4. Means of in VFA and $\mathrm{NH}_{3}$ production in vitro of buffalo treatment ration

\begin{tabular}{|c|c|c|c|c|c|}
\hline \multirow[b]{2}{*}{ Parameter } & \multicolumn{5}{|c|}{ Treatment } \\
\hline & $\mathrm{T}_{1}$ & $\mathrm{~T}_{2}$ & $\mathrm{~T}_{3}$ & $\mathrm{~T}_{4}$ & $\mathrm{~T}_{5}$ \\
\hline & ------------- & ------------- & --(mM)---- & ---------------- & ----------- \\
\hline $\mathrm{NH}_{3}$ & $4.43^{\mathrm{d}} \pm 0.02$ & $4.88^{\mathrm{b}} \pm 0.21$ & $4.73^{c} \pm 0.08$ & $5.20^{\mathrm{a}} \pm 0.02$ & $5.28^{\mathrm{a}} \pm 0.04$ \\
\hline VFA & $123.6^{\mathrm{d}} \pm 3.79$ & $134.8^{\mathrm{c}} \pm 3.79$ & $135.4^{\mathrm{c}} \pm 3.79$ & $140.0^{\mathrm{b}} \pm 0.00$ & $145.4^{\mathrm{a}} \pm 3.79$ \\
\hline
\end{tabular}

Remark: Different superscript shows significant difference in the same line $(\mathrm{P}<0.05), \mathrm{T}_{1}=100 \%$ Leersia hexandra Swartz; $\mathrm{T}_{2}=100 \%$ Neptunia plena $\mathrm{L}$. Benth; $\mathrm{T}_{3}=$ Ration (15\% Neptunia plena L.Benth + $15 \%$ Leersia Swartz hexandra $+70 \%$ other feedstuffs); $\mathrm{T}_{4}=$ Ration $(20 \%$ Neptunia plena L.Benth + $20 \%$ Leersia hexandra Swartz $+60 \%$ other feedstuffs); $\mathrm{T}_{5}=$ Ration $(25 \%$ Neptunia plena L.Benth + $25 \%$ Leersia hexandra Swartz $+50 \%$ other feedstuffs).

Volatile Fatty Acid is the final product of the fermentation process by rumen microbes and acts as an energy source (about $80 \%$ ) for livestock. Buffalo rumen fluid has VFA with the proportion of acetic acid $\left(\mathrm{C}_{2}\right)$ 66.9-73.8\%, propionate $\left(\mathrm{C}_{3}\right)$ 16.2-
$28.8 \%$, butyrate $\left(\mathrm{C}_{4}\right)$ 4.7-6.6\% (Hart et al., 2007; Wanapat and Rowlinson, 2007; Mayulu, 2015). The means of in vitro VFA production of buffalo ration based on local feed (Table 4), based on ANOVA shows that the means value of the highest VFA 
production was $\mathrm{T}_{5}=145.4 \mathrm{mM} ; \mathrm{T}_{4}=140.00$ $\mathrm{mM} ; \mathrm{T}_{3}=135.40 \mathrm{mM} ; \mathrm{T}_{2}=134.80 \mathrm{mM}$ and $\mathrm{T}_{1}=123.60 \mathrm{mM}$. Duncan multiple range test shows the production of VFA from $\mathrm{T}_{5}$ $(145.40 \mathrm{mM})$ was significantly higher ( $P$ $<0.05$ ) compared to $\mathrm{T}_{4}, \mathrm{~T}_{3}, \mathrm{~T}_{2}$, and $\mathrm{T}_{1}$. VFA concentration produced in this study was in the normal range (80-160 $\mathrm{mM}$ ) to support optimum microbial growth. VFA concentration is affected by the quality of the ration, the type of feed carbohydrate, the physical form of the feed, the level of fermentability of feedstuff, and the number and types of bacteria present in the rumen. High VFA concentration indicates increased rumen microbial activity because more organic matter is fermented in the rumen and indicates that the fermentation process is more effective than the ordinary one, however too high VFA concentration can disrupt the rumen system balance (Madrid et al., 2002; Mayulu, 2015).

\section{CONCLUSION}

In vitro digestibility and fermentation ruminant of buffalo ration based on Neptunia plena L. Benth and Leersia hexandra Swartz as local resources can buffalo improved ruminant fermentation so that it is capable of increasing the buffalo productivity.

\section{ACKNOWLEDGEMENT}

The author express gratitude and appreciation to the head and staff of the Laboratory of Animal Nutrition, Faculty of Animal Husbandry and Agriculture, Diponegoro University, Semarang, who have provided facilities and supported the research.

\section{REFERENCES}

Aderinboye, R., Akinlolu, A., Adeleke, M. A., Najeem, G., Ojo, V. O. A., Isah, O. A., \& Babayemi, O. J. (2016). In vitro gas production and dry matter degradation of four browse leaves using cattle, sheep and goat inocula. Slovak Journal of Animal Science, 49(1), 32-43.
AOAC. (1990). Official Methods of Analysis. United States of America.

Christiyanto, M., Soejono, M., Utomo, R., Hartadi, H., \& Widyobroto, B. P. (2005). The nutrient digestibility of different protein-energy precursor rations in dairy cattle fed on a basal diet of king grass. Journal of the Indonesian Tropical Animal Agriculture, 30(4), 242-247.

Dijkstra, J., Kebreab, E., Bannink, A., France, J., \& Lopez, S. (2005). Application of the gas production system for ruminants. Animal Feed Science and Technology, 123(124), 561-578.

Goes, R. H. T., Silva, L. H. X., Diaz, T., Branco, A. F., Teodoro, A. L., \& Ferreira, G. R. (2019). Sunflower cake in diets for beef cattle: Digestibility, kinetics and in vitro ruminal fermentation parameters. Acta Scientiarum - Animal Sciences, 41(1), 1-8. https://doi.org/10.4025/actascian imsci.v41i1.39429

Hart, K. J., Yáñez-Ruiz, D. R., Duval, S. M., McEwan, N. R., \& Newbold, C. J. (2008). Plant extracts to manipulate rumen fermentation. Animal Feed Science and Technology, 147(1-3), 835. https://doi.org/10.1016/j.anifeed sci.2007.09.007

Khanum, S. A., Yaqoob, T., Sadaf, S., Hussain, M., Jabbar, M. A., Hussain, H. N., REHMAN, S. (2007). Nutritional evaluation of various feedstuffs for livestock. Pakistan Vet. $J, 27(3), 129-133$.

Mabjeesh, S. J., Cohen, M., \& Arieli, A. (2000). In vitro methods for measuring the dry matter digestibility of ruminant feedstuffs: comparison of methods and inoculum source. Journal of Dairy Science, 83(10), 2289-2294. https://doi.org/10.3168/ jds.S0022-0302(00)75115-0

Madrid, J., Dolores Megías, M., \& Hernández, F. (2002). In vitro determination of ruminal dry matter and cell wall degradation, and 
production of fermentation endproducts of various by-products. Animal Research, 51(3), 189-199. https:// doi.org/10.1051/animres:2002018

Makkar, H. P. S. (2004). Recent Advances in the in Vitro Gas Method for Evaluation of Nutritional Quality of Feed Resoures. In FAO (Ed.), Assessing quality and safety of animal feeds (pp. 55-88). Rome (Italy): FAO.

Mayulu, H. (2014). The nutrient digestibility of locally sheep fed with amofer palm oil byproduct-based complete feed. International Journal of Science and Engineering, 7(2), 106-111. https://doi.org/10.12777/ijs e.7.2.106-112

Mayulu, H. (2015). Cattle Feeding and Breeding Activity Efficiency. In Pakan Sapi Potong dan Efisiensi Usaha Penggemukan. Semarang: Unnes Press.

Mayulu, H., Fauziah, N., Christiyanto, M., Sunarso, S., \& Haris, M. I. (2019). Digestibility value and fermentation level of local feed-based ration for sheep. Animal Production, 20(2), 95102. https://doi.org/10.20884/1.jap.20 18.20.2.706

Ministry of Agriculture. (2018). Statistic Book of Animal Husbandry and Animal Health. In Buku Statistik Peternakandan Kesehatan Hewan. South Jakarta.

Mohamed, R., \& Chaudhry, A. S. (2008). Methods to study degradation of ruminant feeds. Nutrition Research Reviews, 21(1), 68-81. https://doi.org/ 10.1017/S0954422408960674

Mould, F. L., Kliem, K. E., Morgan, R., \& Mauricio, R. M. (2005). In vitro microbial inoculum: A review of its function and properties. Animal Feed Science and Technology, 123-124, 31-50. https://doi.org/10.1016/j.anife edsci.2005.04.028

Nanda, A. S., \& Nakao, T. (2003). Role of buffalo in the socioeconomic development of rural Asia: Current status and future prospectus. Animal
Science Journal, 74(April), 443-455. Phesatcha, K., \& Wanapat, M. (2015). Improvement of nutritive value and in vitro ruminal fermentation of leucaena silage by molasses and urea supplementation. Asian-Australasian Journal of Animal Sciences, 29(8), 1136-1144. https://doi.org/10.5713/aj as.15.0591

Rodríguez, M. A. B., Solorio-Sánchez, F. J., Sandoval-Castro, C. A., Klieve, A., Rojas-Herrera, R. A., Briceño-Poot, E. G., \& Ku-Vera, J. C. (2015). Rumen function in vivo and in vitro in sheep fed Leucaena leucocephala. Tropical Animal Health and Production, 47(4), 757-764. https://doi.org/10.1007/s11 250-015-0790-y

Sarwar, M., Khan, M. A., Nisa, M., Bhatti, S. A., \& Shahzad, M. A. (2009). Nutritional management for buffalo production. Asian-Australasian Journal of Animal Sciences, 22(7), 1060-1068. https://doi.org/10.5713/aj as.2009.r.09

Sugoro, I., Wiryawan, K. G., Astuti, D. A., \& Wahyono, T. (2015). Gas production and rumen fermentation characteristics of buffalo diets containing by-product from some sorghum varieties. Jurnal Ilmu Ternak Dan Veteriner, 20(4), 242-249. https: //doi.org/10.14334/jitv.v20i4.1241

Sunarso. (2003). Ruminant Feeds in Integrated System of LivestockAgriculture. In Professor Inauguration Speech of Diponegoro University. Semarang: Diponegoro University Publisher.

Sutardi, T. (2001). Revitalization of cattle farms through the use of waste-based rations and organic mineral supplements. In Research on RUT VIII.1. Bogor: State Ministry of Research and Technology together with the Indonesian Institute of Sciences.

Tilley, J. M. A., \& Terry, R. A. (1963). A two-stage technique for the in vitro digestion of forage crops. Grass and 
Forage Science, 18(2), 104-111. https://doi.org/10.1111/j.1365-2494.1 963.tb00335.x

Wanapat, M., Kang, S., \& Phesatcha, K. (2013). Enhancing buffalo production efficiency through rumen manipulation and nutrition. Buffalo Bulletin, 32(1), 258-275.
Wanapat, M., \& Rowlinson, P. (2007). Nutrition and feeding of swamp buffalo: feed resources and rumen approach. Italian Journal of Animal Science, 6(sup2), 67-73. https:// doi.org/10.4081/ijas.2007.s2.67 